\title{
تأثثير جماعات الضغط والأحزاب السياسية في القرار السياسي
}

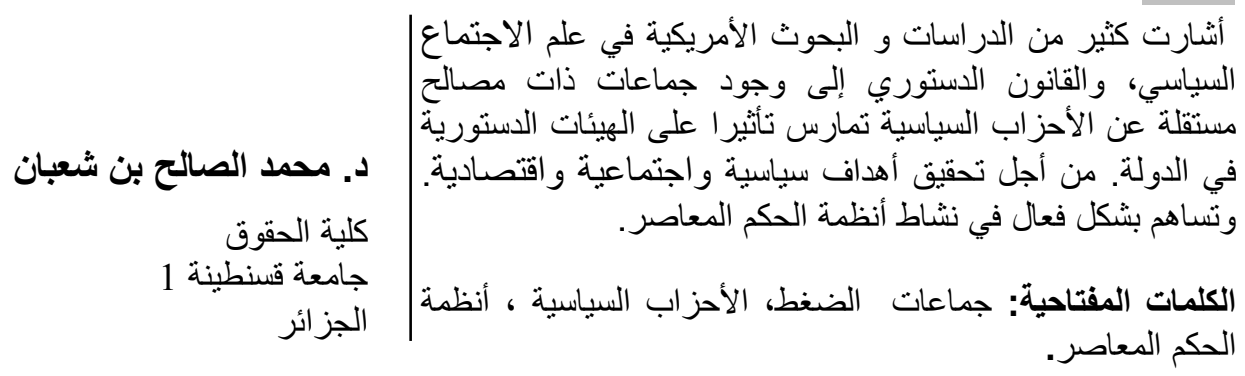

\section{مقدمة}

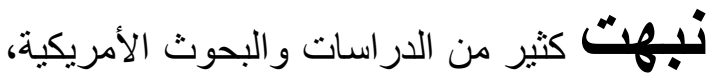

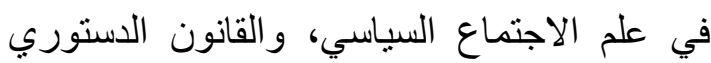

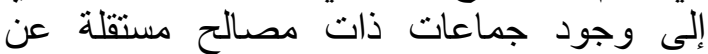

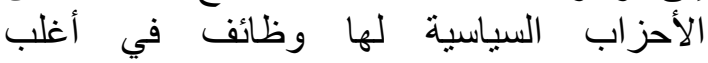

The global financial crisis has

Many American studies and

scholars in political sociology and

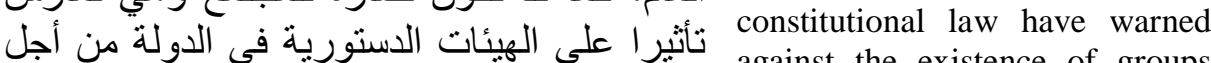

against the existence of groups

who have independent interests

(1) from the political parties and

exert an influence on the

constitutional bodies in the state, تمثنان تجمعات بشرية تعمل كل منهما بوسائلها social and economical goals.

(2). وتتسع عند الأولى وتتحدد وتضيق عند الثنانية These groups contribute Key Terms: influence groups, مستترة تؤثر على النظام السياسي، وتحركه regimes activity. 
بجانب القوة الظاهرة أو كما تسمى بالحكام الظاهرين.(3)

ولما كانت جماعات الضغط تساهم بشكل فعال إلى جانب الأحز اب النئ السياسية في

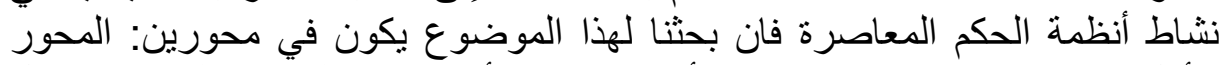

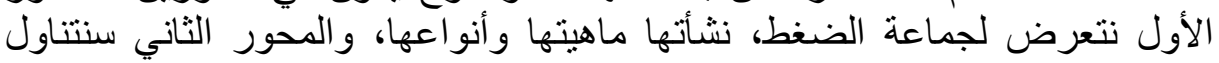

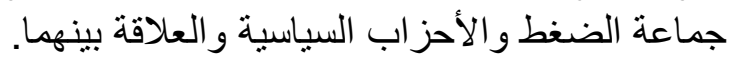

أولا : جماعة الضغط ماهيتها وأنواعها

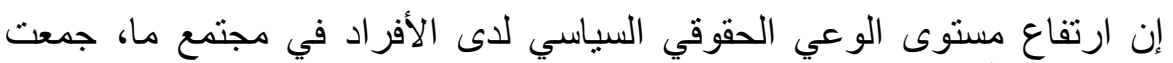

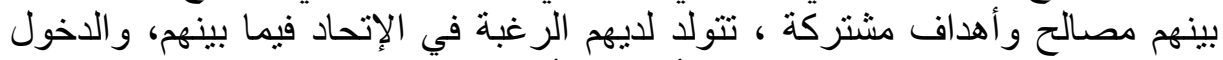

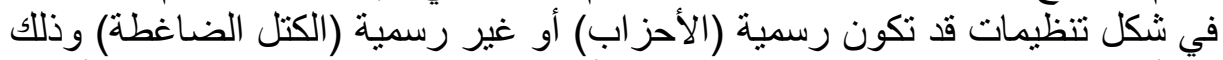

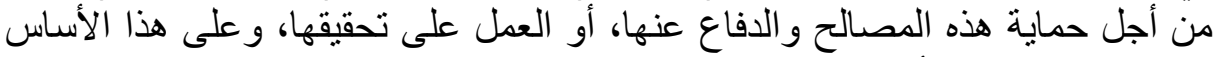

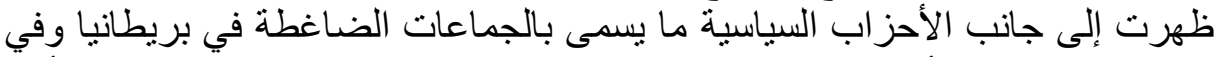

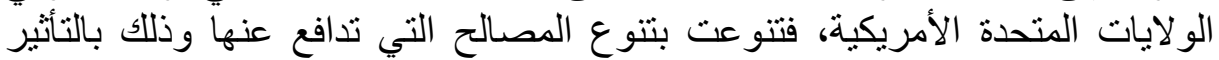

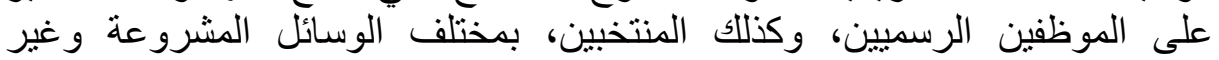

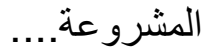

\section{الفرع الأول}

\section{1- تعريف جماعة الضغط}

الجماعات الضاغطة هي تللك الجماعات التي تضم مجمو عة من الأفر اد يتحدون في

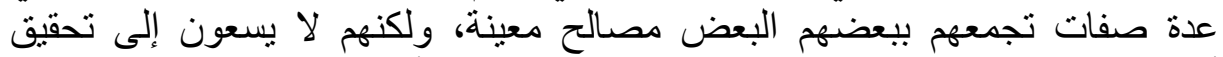

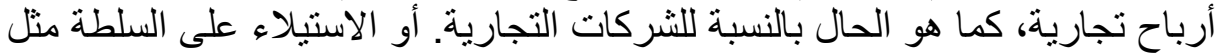

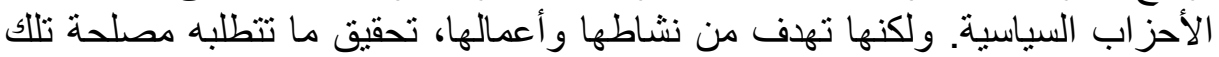

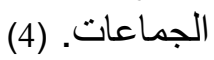

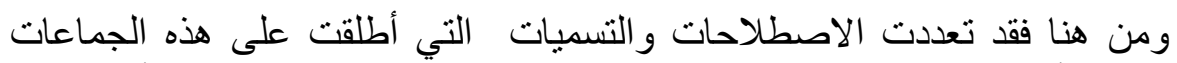

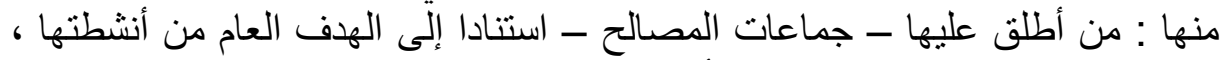

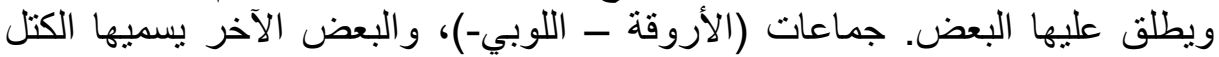

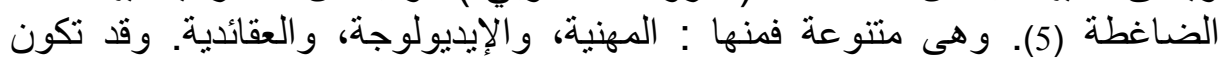

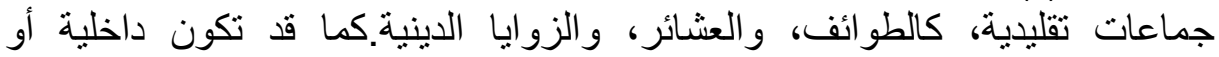

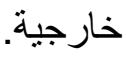

لقد تعددت جماعات الضغط في مختلف الدول، بتعدد المصالح التي نشأت للافاع التهاع

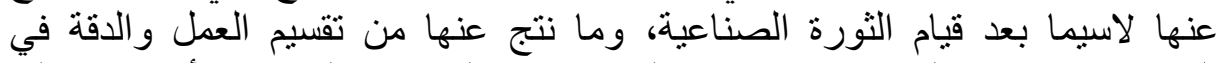

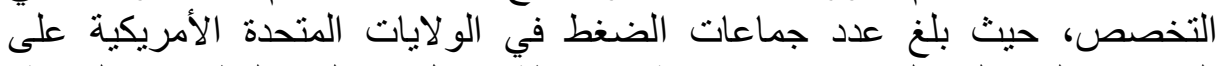

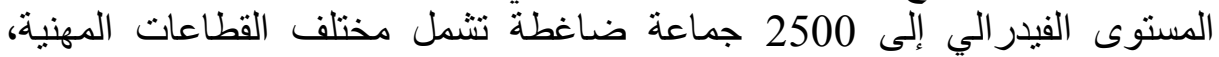
و الصناعية، والتجارية ..الخ (6). ومن أجل تحقيق أهدافها وحماية مصالحها،فإنها 
تلجأ إلى استعمال مختلف الأساليب والوسائل ، الآتي توضيحها.

2 - وسائل عملهــانـا

تتضح فاعلية جماعة الضغط من خلال وسائل الضغط التي تستعملها في عملياتها السياسية ويتوقف نجاحها أو فثلها على كيفية استعمال هذه الوسائل ومدى تقبل النظام السياسي لها ، نذكر على سبيل المثال بعضا من هذه الوسائل:

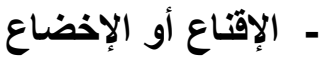

يعتبر الإقناع الطريق العادي التي تسلكه جماعات الضغط مع كافة الإنهات الجهات محل

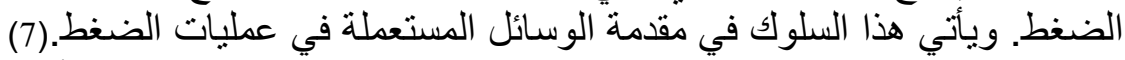
ويتم ذللك عن طريق الحوار والمناقثنة مع السلطة المعنية ( التشريعية أو التنفيذية التئية

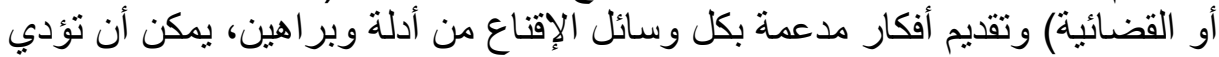

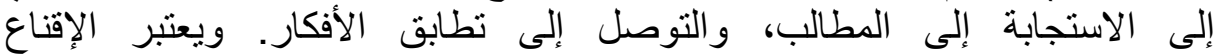

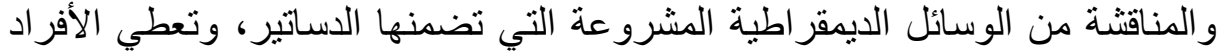

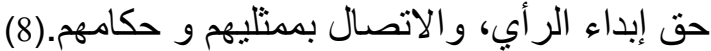

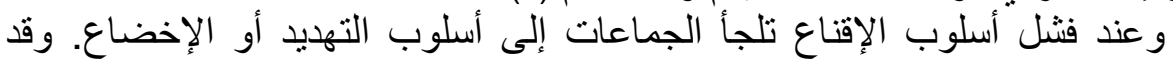

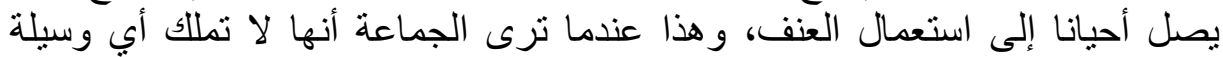

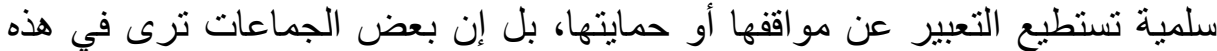

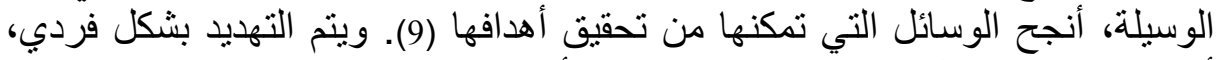

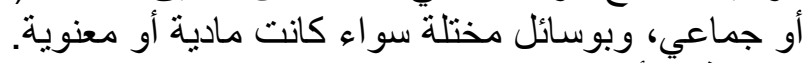

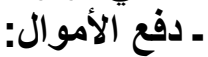

يعتبر المال الركيزة الأولى والهامة التي تستند إليها جماعات الضغط في سبيل

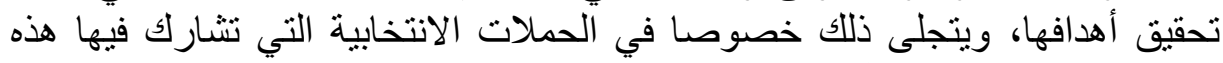
الجماعات تدعم بعض المترشحين، الذين ترى في فوز هم بالانتخاب فرصة لتهن لتحقيق أهدافها.

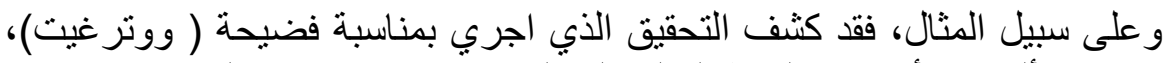

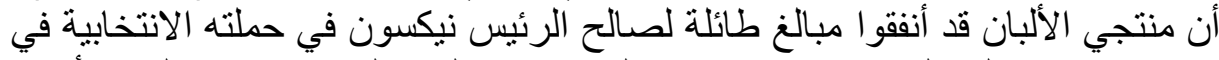

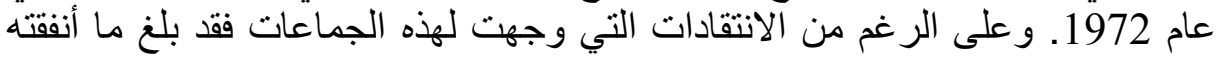
في الحملات الانتخابية للكونغرس لعام 1974 ما يزيد عن ملونين و نصف مليون

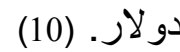
كما قامت الجمعية الطبية الأمريكية - AMA - بإنفاق أكثر من مليون دولار في

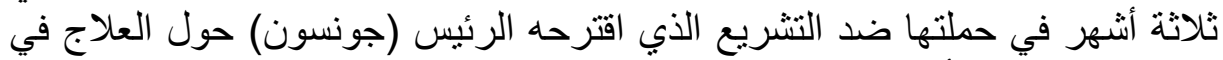
الو لايات المتحدة الأمريكية.(11) 


\section{- - وسيائل الإعلام واستمالة الرأي العام:}

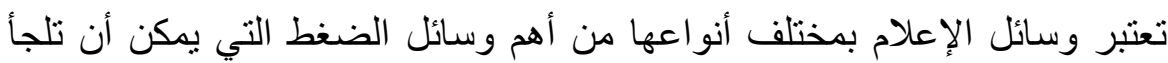

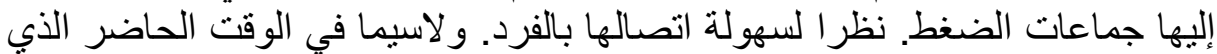

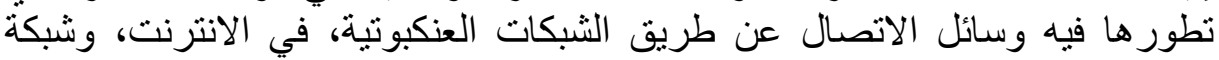

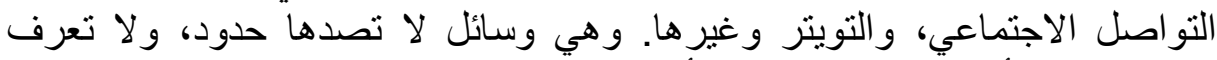

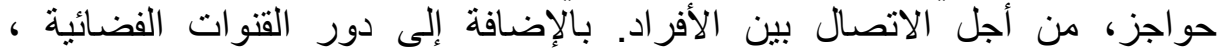

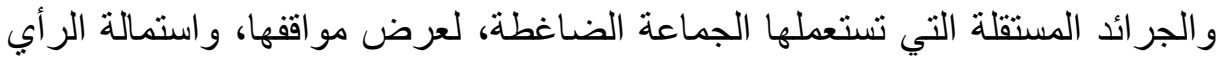

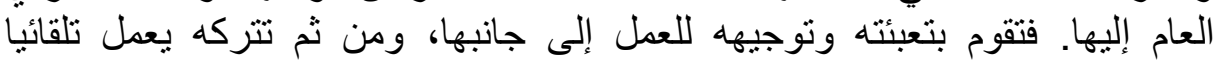

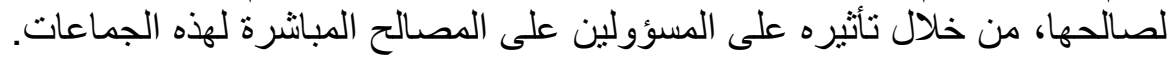

\section{3- أنواع جماعات الضغط}

و على ضوء ما تقدم في تعريف جماعات الضغط و الوسائل التي تستعملها في

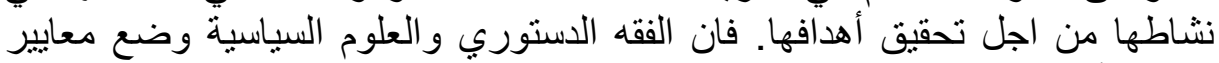

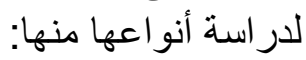

$$
\text { - }
$$

أما المعيار الأول: فيتعلق بالهدف الذي تسعى الجماعة إلى تحقيقه، وتبعا لهذا إذاءل المعيار تتقسم إلى: جماعات مهنية، وجماعات عقائدية ذات النزية عة الأيديولوجية.

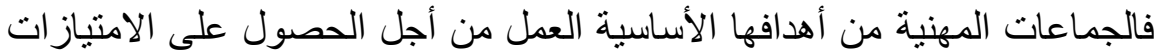

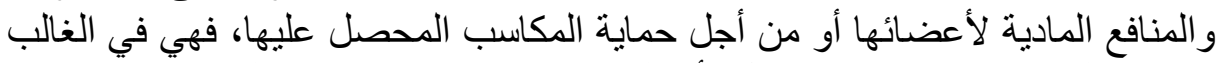

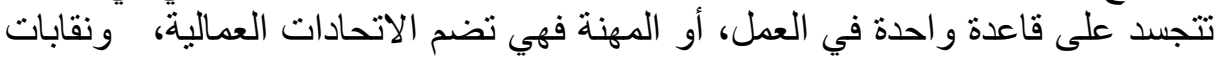

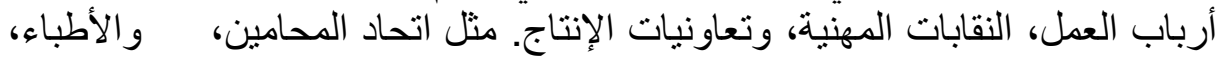

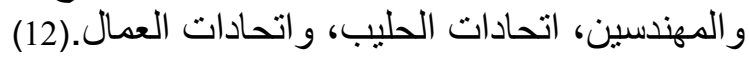

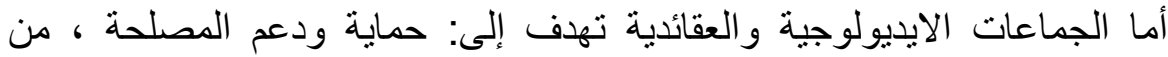

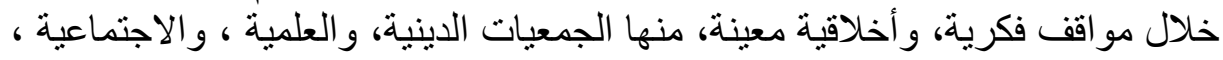

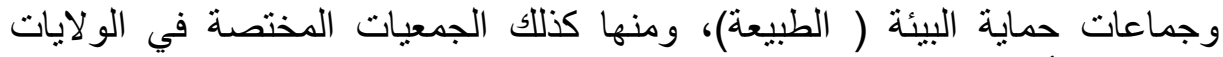

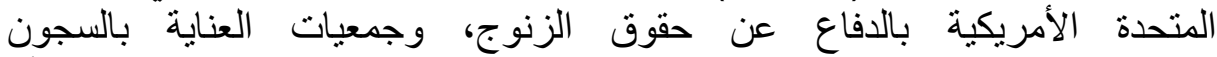

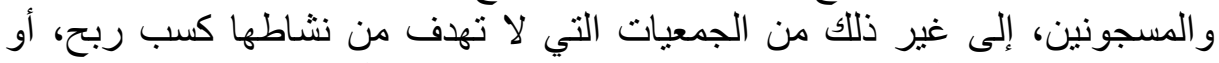

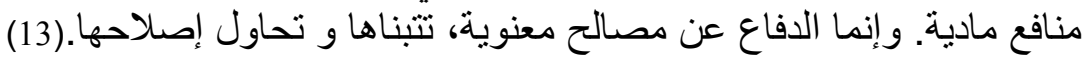

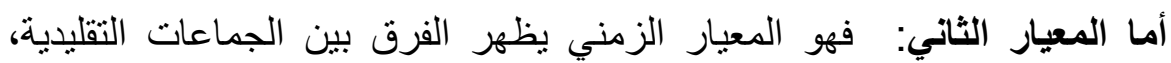
و الجماعات الحديثة، ويتجلى ذللك واضحا في البلدان النامية، وفي الدول العربية.(14) 
فالجماعات التقليدية، هي المنظمات القديمة كالطوائف، و الأسر الإقطاعية،

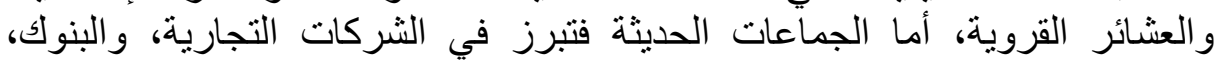
وجمعيات التجار ، و الصناع و المز المعار عين.

أما المعيار الثالث: وهو المعيار المكاني فتقسم إلى: جماعات داخلية، و هي التي التي

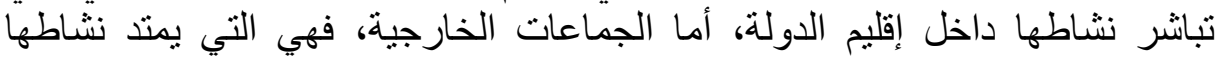

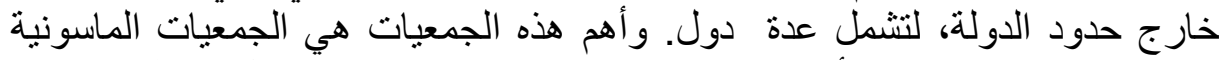

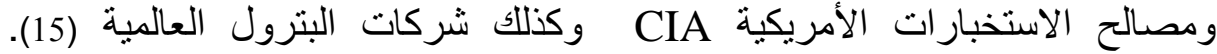

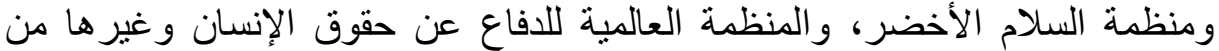
المنظمات غير الحكومية. وعلى هذا الأساس برزت الفاعة محاولات لات كثيرة لتصنيف

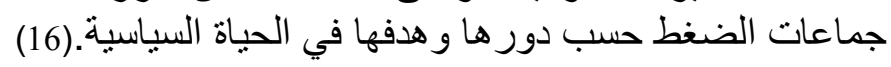

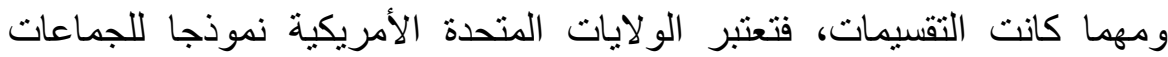

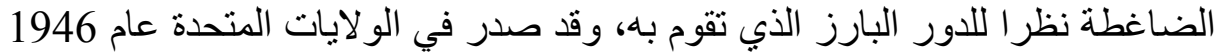

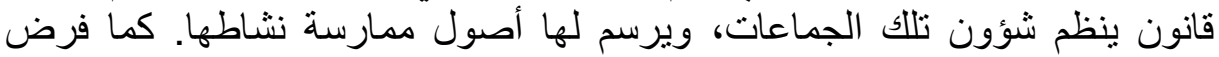

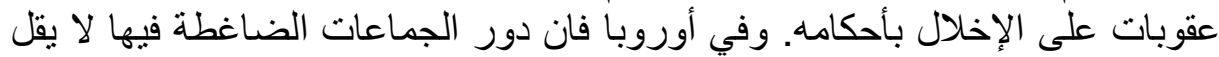

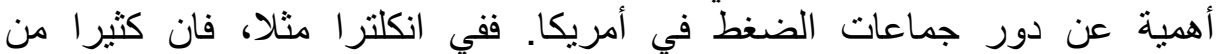
مشرو عات القوانين الحكومية تعرض على الى جماعات الضغط الضي التي تعنيها هذه القوانين،

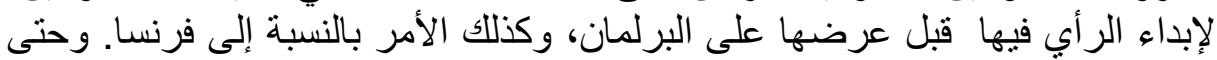

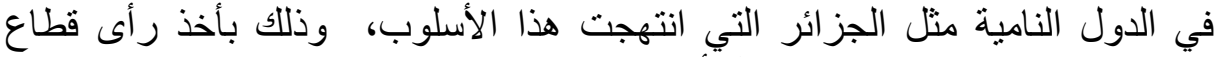

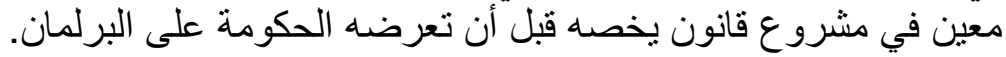

\section{ثناتيا جماعات الضغط والأحزاب السياسية والعلاقة بينهما}

إن الأحزاب السياسية وجماعات الضغط تمثلان تنظيمات بشرية تعمل كل منهما

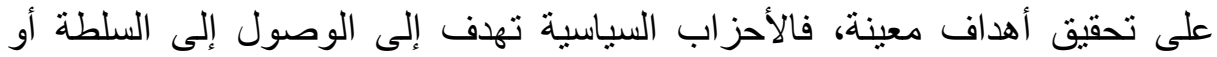

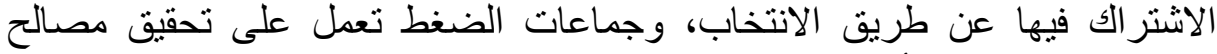

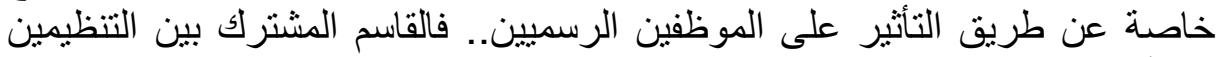

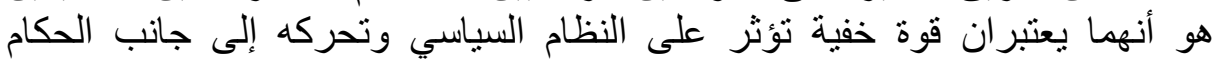

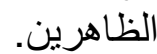

و عليه. فإن العلاقة بين الأحز اب السياسية والجماعات الضاغطة لها أهمية كبرى،

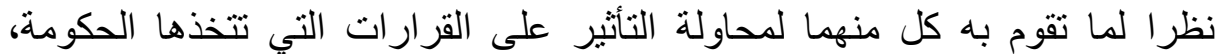

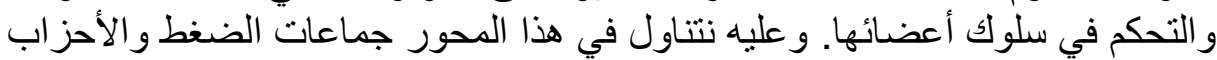
السياسية. و العلاقة بينهما

\section{- جماعة الضغط والأحزاب السياسية ولية}

عرفنا فيما تقدم أن الجماعة الضاغطة تضم مجموعة من الناس يتحدون في عدة

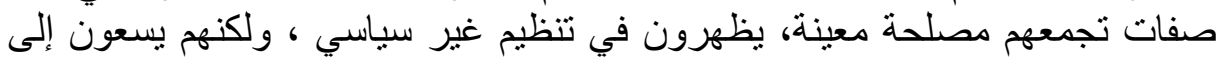




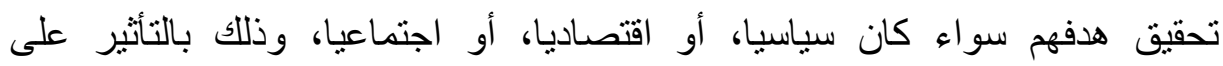
السلطات العامة في الدولة، بوسائل مختلفة مشروعة وقدان تكون غير مشروعة في

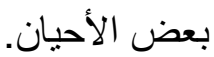

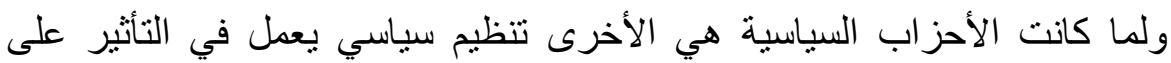

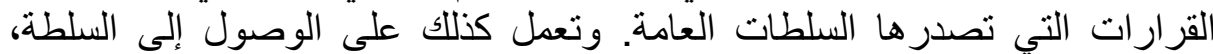

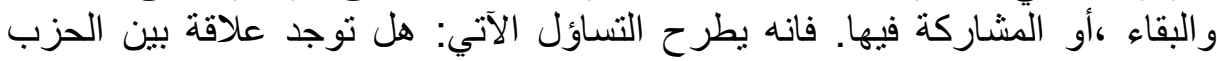

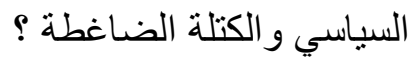

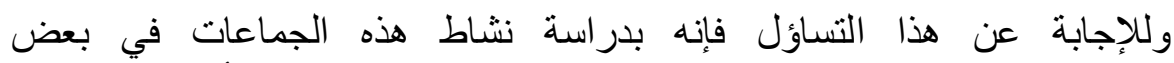

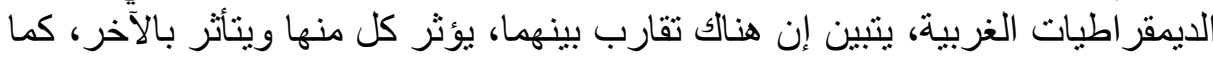

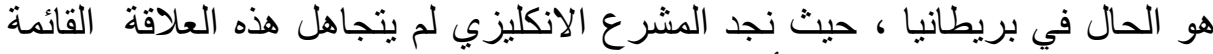

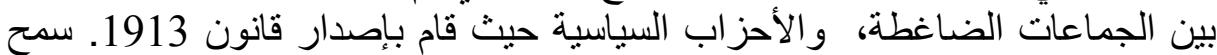

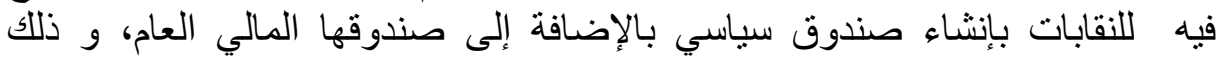

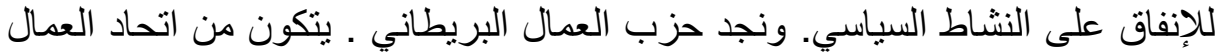

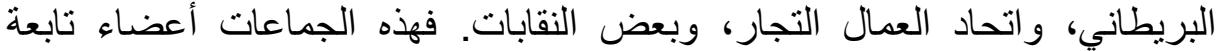

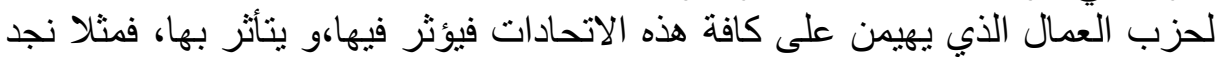

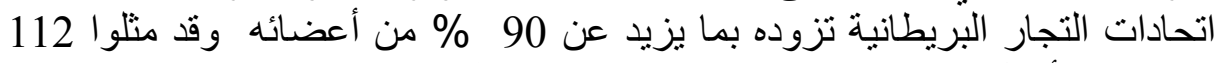

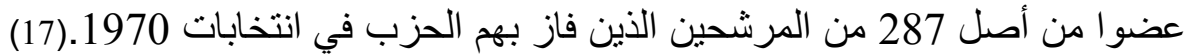

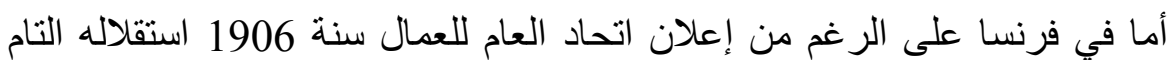

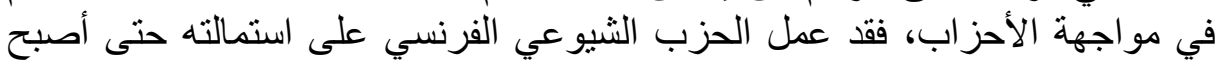
ملحقا باه. (18) ماجة الاحزي

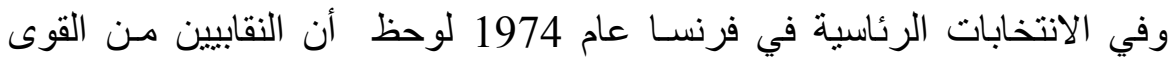

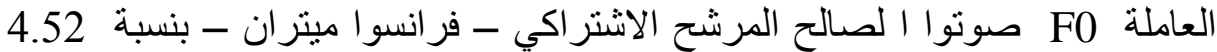
بينما صوت 48 \% لصالح مرشح اليمين و الوسط ، - جيسكار ديستان.

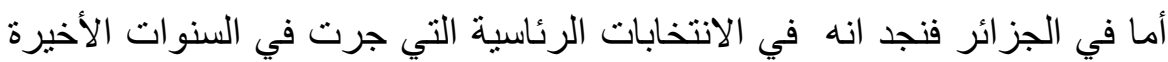

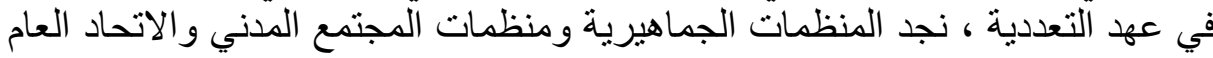

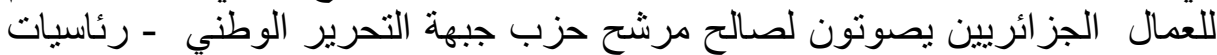
1999 وما بعدها.

ورغم هذه العلاقة القائمة بين الكتل الضاغطة والأحزاب السياسية فانه توجد

ففي الولايات المتحدة الأمريكية، نجد اللوبي اليهودي، لله دور هام في توجيه بلوبيه

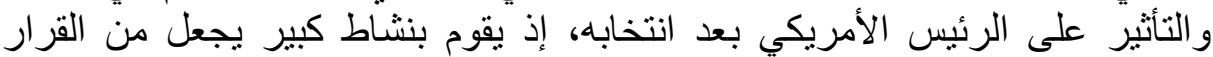

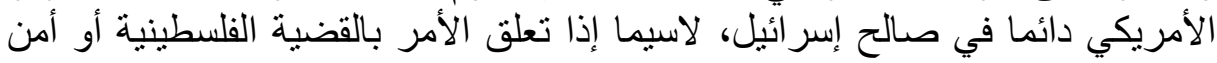


كما قد تلتقي الجماعات الضاغطة بالأحزاب السياسية في الأنظمة ذات الحكم

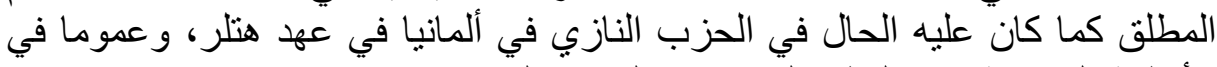

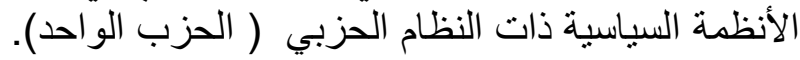

\section{ـ العلاقة بين جماعة الضغط والأحزاب السياسية}

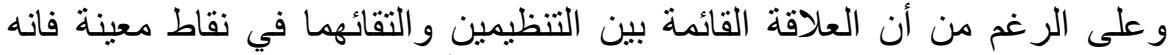

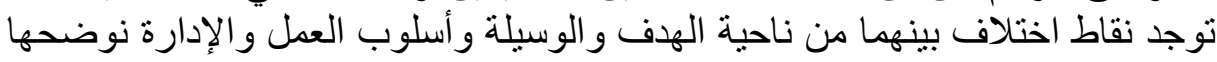

$$
\text { أولا : من حيث الهذف : من }
$$

فالجماعات الضاغطة تتميز عن الأحزاب السياسية ، بكونها لا تملك الرغبة في

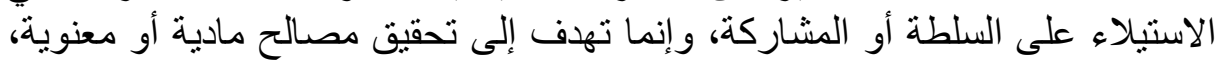

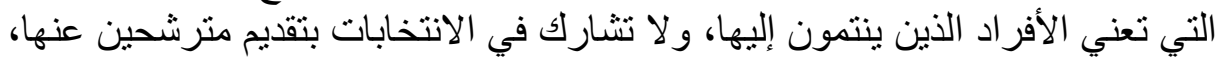

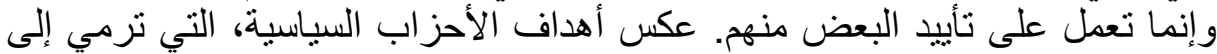

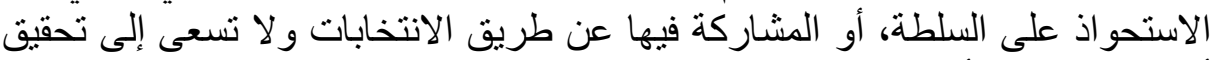

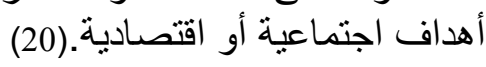

\section{ثانيا: من حيث الوسيلة}

تستعمل الجماعات الضاغطة كل الوسائل المشروعة، وغير المشروعة، سرا

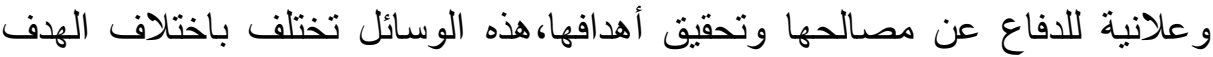

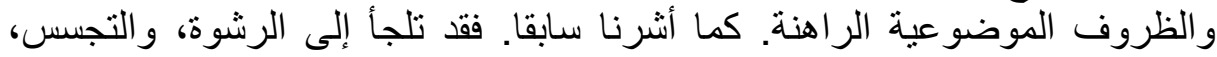
للحصول على معطيات معينة أو تستعمل أسلوب التر غيب و الترهيب. لأن الغاية عندها

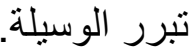

بينما الأحز اب السياسية، فإنها من حيث الظاهر تستعمل الوسائل المشرو عة لتحقيق

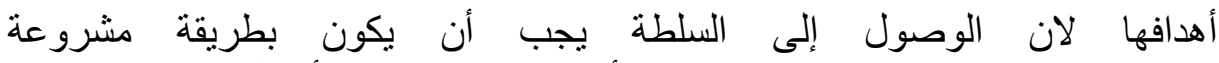
وديمقراطية، وهي الانتخابات. إذا ثبت أن الحزب قد قام بأبة ألعمال مخالفة للقانون

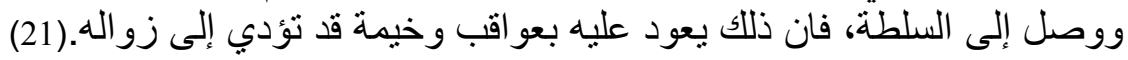

\section{ثالثا: من حيث طريقة العمل}

إن أسلوب عمل الكتل الضاغطة، هو أسلوب وقائي، أي أنها تهتم بأعمال السلطة

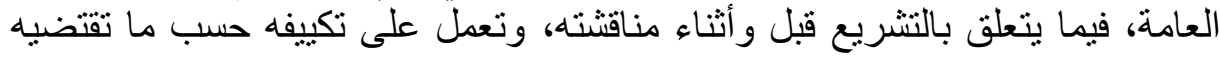

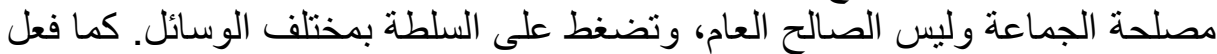

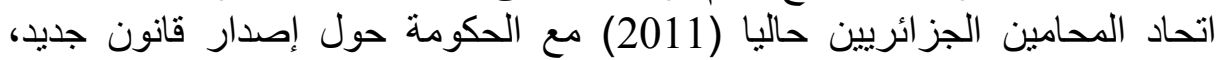

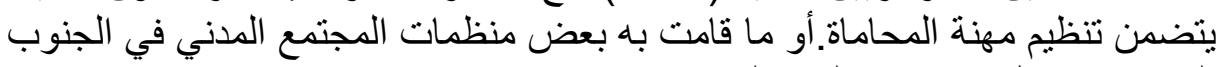
الجزائري حول استخر اج الغاز الصخري.

في حين نجد الأحزاب في الغالب تقوم بدور علاجي، أي الاهتمام بما هو قائم إنائ

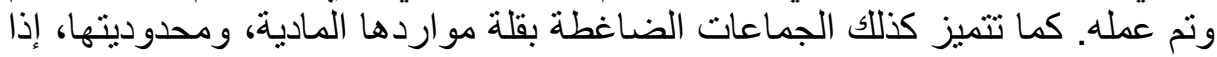


ما قورنت بإمكانيات الأحزاب السياسية. وإن كانت هذه المسألة الأخيرة تعتبر نسبية.

$$
\text { رابعا: من حيث الإدارة والتسيير }
$$

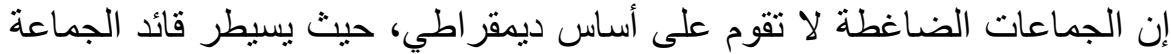

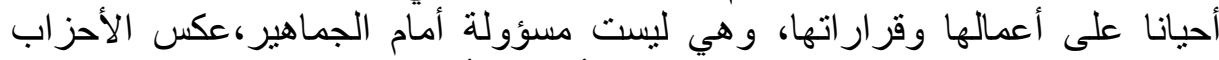

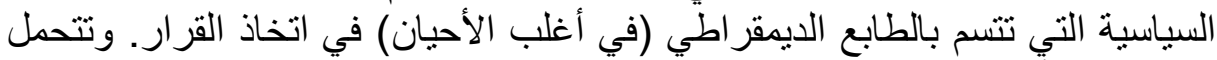

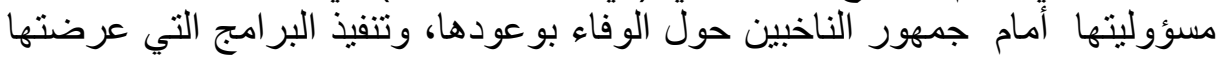
في الحملة الانتخابية.

\section{- ديمقر اطية جماعة الضغط}

و ولى الرغم من الدور الذي تلعبه الجماعات الضاغطة في السياسة العامة في

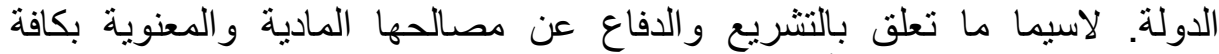
الوسائل، فان الفقه انقسم بشأنها إلى فريقين بين معارض وض ومؤيد.

\section{أولا المعارضون لجماعات الضغط :}

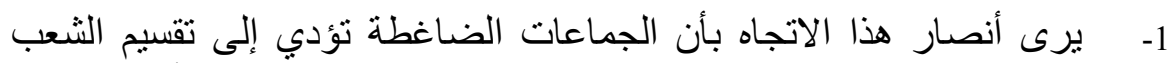

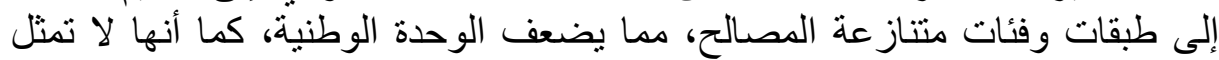

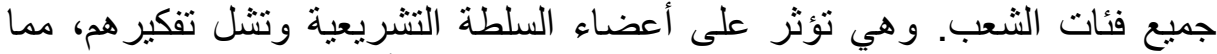

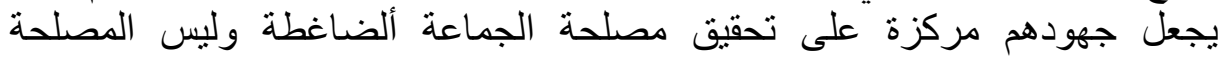
العامة. (22)

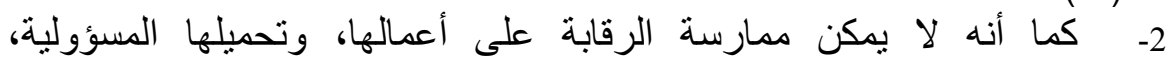

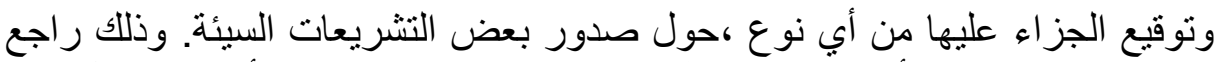

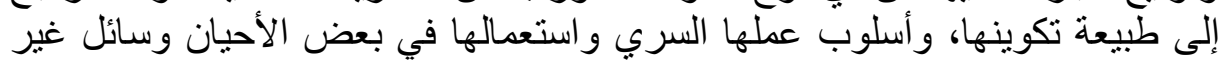

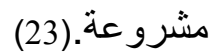
3- بالإضافة إلى ذلك فإن جماعات الضغط تؤدي إلى تجاهل المصلحة العامة ن

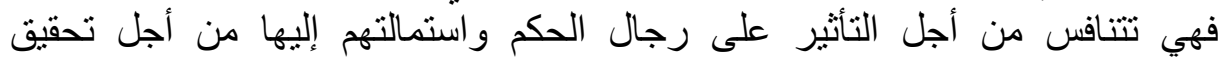

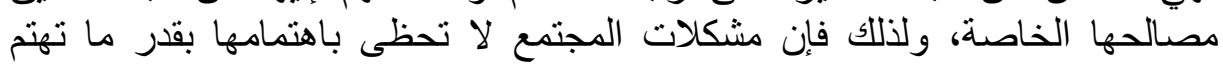
بحماية مصالحها. 4- تؤدي جماعات الضغط إلى إضعاف الوحدة الوطنية، وتقسم الكل إلى أجزاء

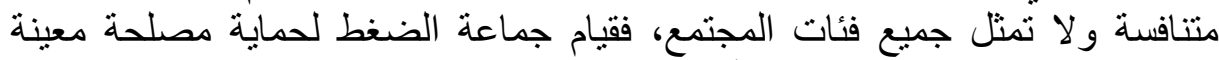

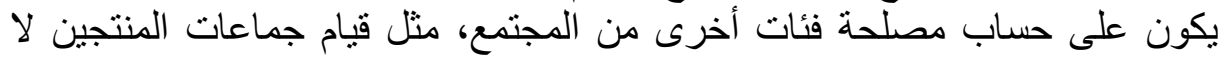
تقابلها جماعة ضغط المستهلكين وكل هذا يؤثر على مبادئ الدئ الديمقراطية التي تقوم

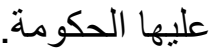

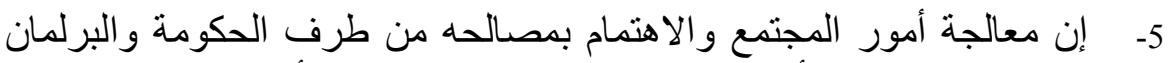

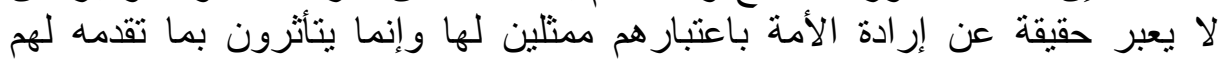

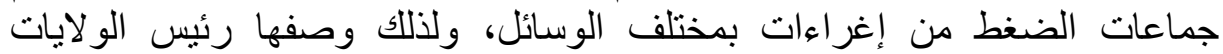


المتحدة الأمريكية (هاري ترومان) " بأنها مدمرة للحكومات البرلمانية وتعيق الدولة

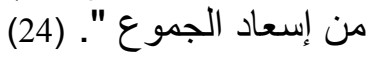

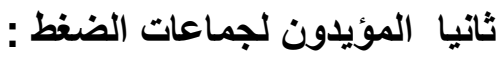

على الرغم من سهام النقد التي وجهت إلى جماعات الضغط إلا أن أن لها مادحين

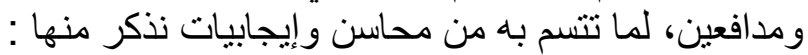

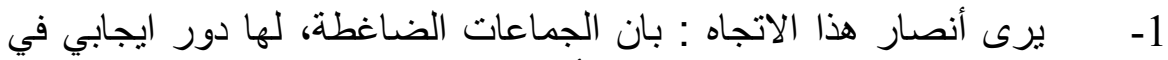

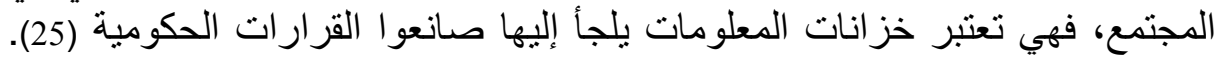

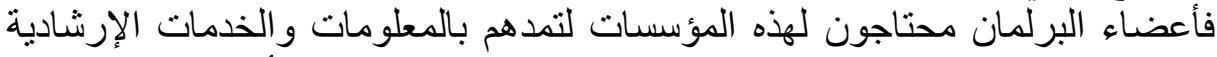

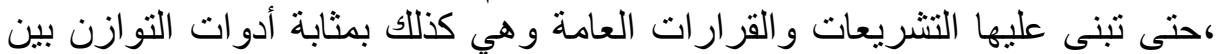
السلطتين التشريعية و التنفيذية (26).

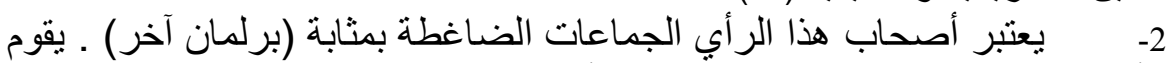

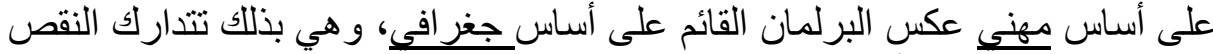

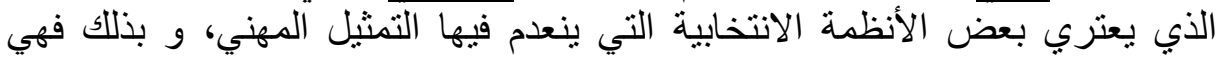
مجألس معاونة للسلطتين التشريعية والتنفيذية.

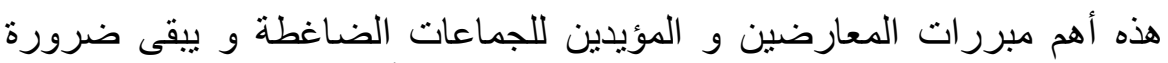

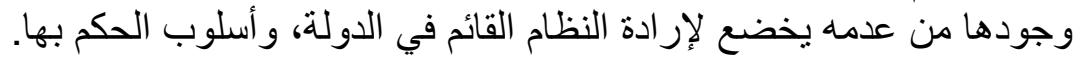

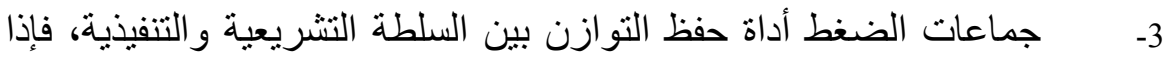

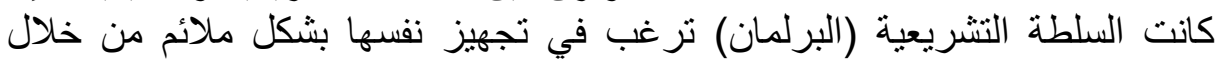

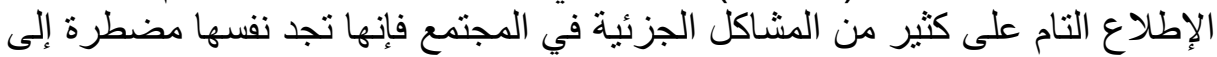

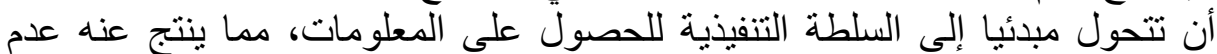

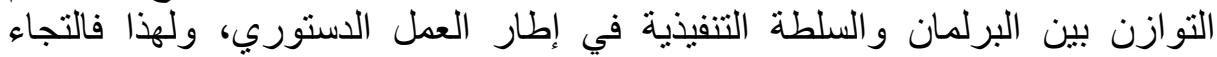

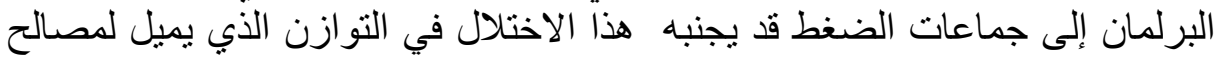
السلطة التنفيذية. (28)

4- جماعات الضغط تزود العمل السياسي بروح التعاون و الثعور بالمسؤولية

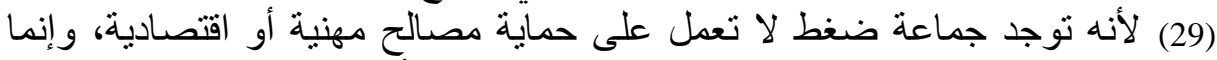

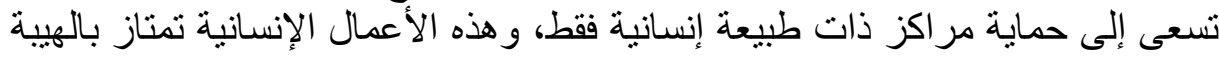

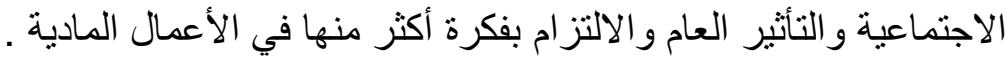

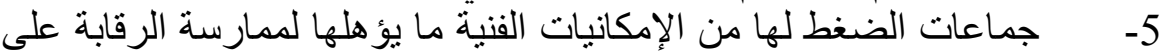

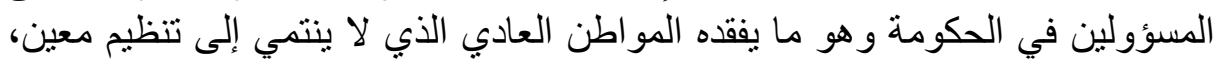

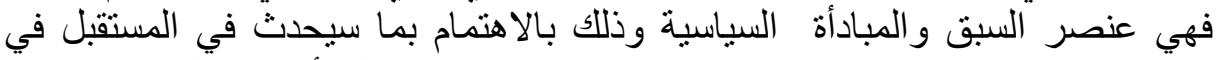

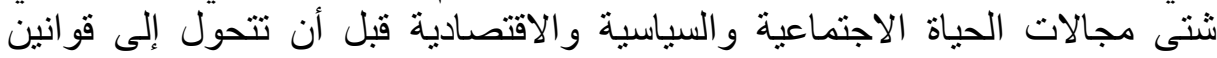
وقرارات غير مستو عبة سواء على المستوى الحكومي أو الثعبي. هذه أهم ما قيل في جماعات الضغط سواء من المادحين أو القادحين ولكن أيا منها 
لم يتخذ موقفا صارما فيها سواء بمنعها أو تنظيمها، وذللك لأن الحكام في قرارة أنفسهر

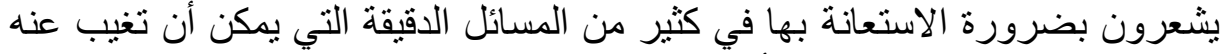

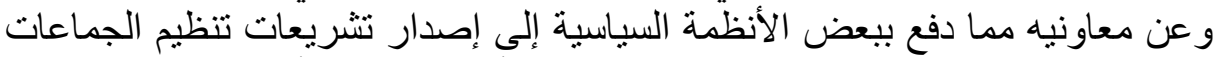
الضاغطة مثل ما حدث في الولايات المتحدة الأمريكية التي أصدانية الصدرت سنة 1946

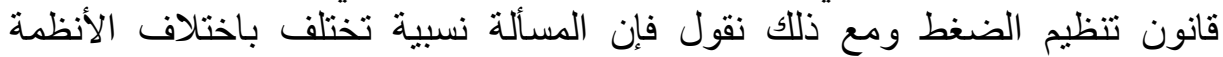
وطبيعة العلاقة بين مؤسساتها الرسمية وغير الرسمية.

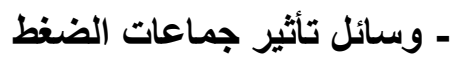

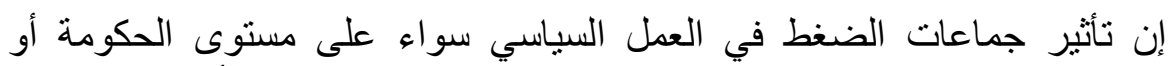
البرلمان يرجع إلى عدة عو امل تشكل مصدر قوة جماعات الضير الضغط في أب ظرف كانى

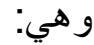

\section{أولا عدد الأعضاء :}

يحتل العنصر البشري في جماعات الضغط أهمية كبرى في عمل جماعة الضغط أنغاء

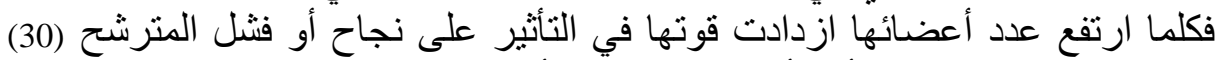

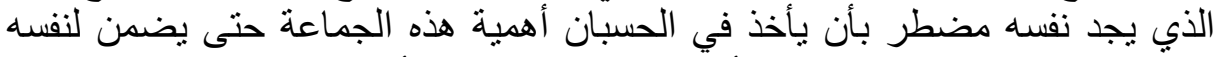

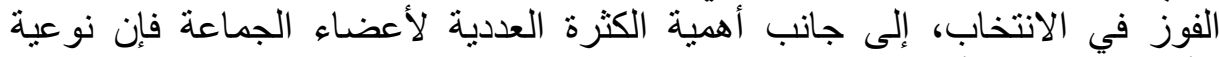

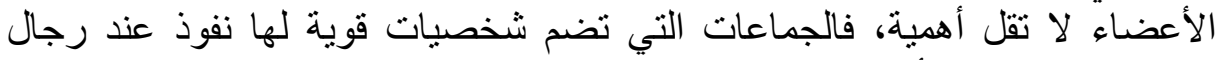

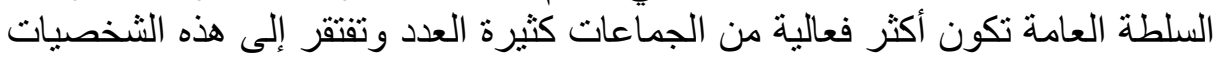

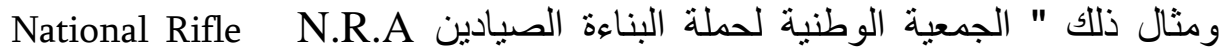

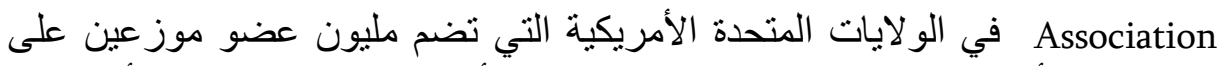

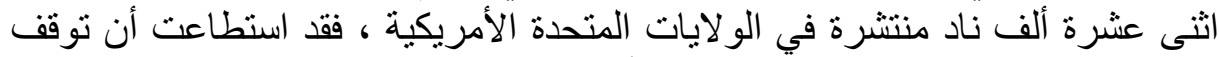

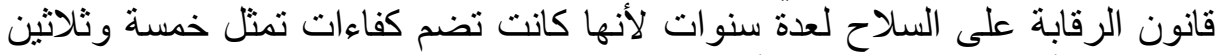
عضوا من أعضاء الكونغرس الأمريكي.(31)

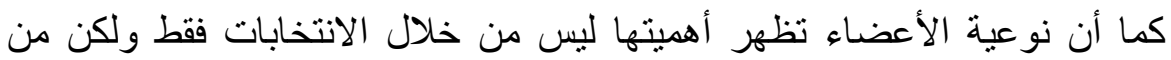

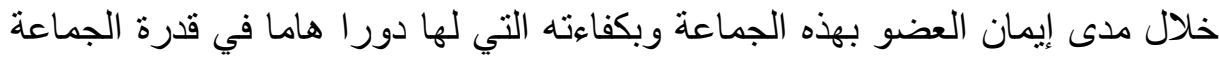
الضاغطة.

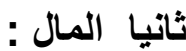

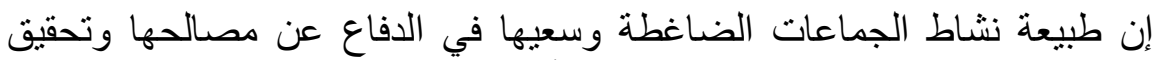

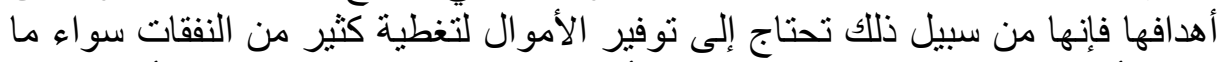

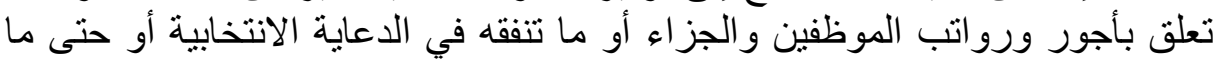

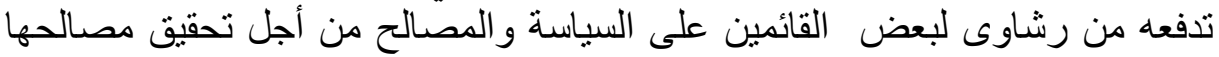

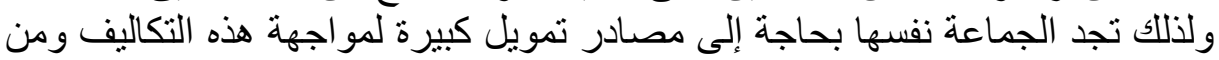

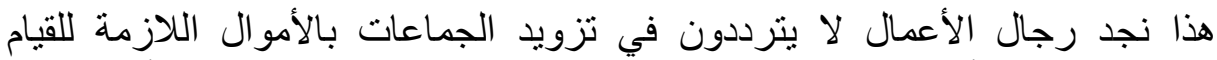

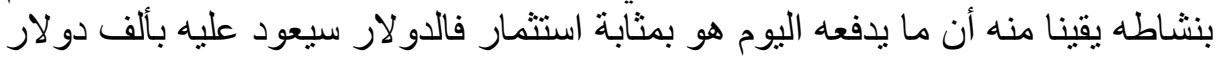


مستقبلا ن وقد وصف Jesse Unrah جاس أونر اللك بقوله : المال هو حليب الأم بالنسبة للسياسة " . " Money is the mother's milk of politics " . (32) ثنالثا التنظيم : بالث

إذا كان التنظيم يمثل الثكل الذي تفرغ فيه الجهود الجماعية لتحقيق غرض محدد

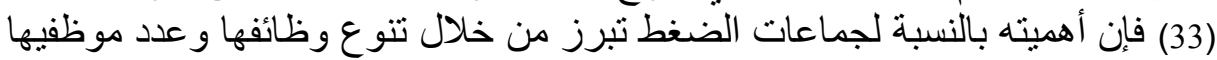

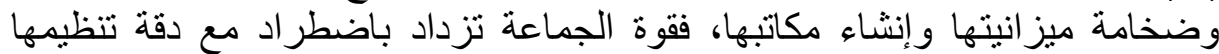
القادر على ربط كافة جو انبها وبالتالي إيجاد نوع من التنسيق المتبادل بينهما.

ويربط بعض الفقهاء دقة تنظيم الجماعة بالقدرة على المحافظة على مسيرتها

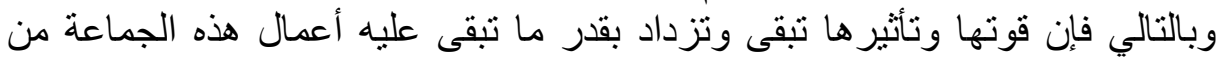

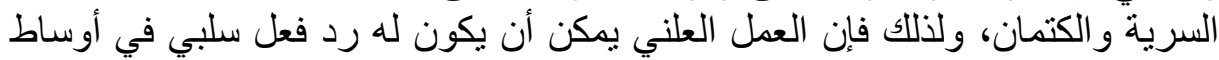

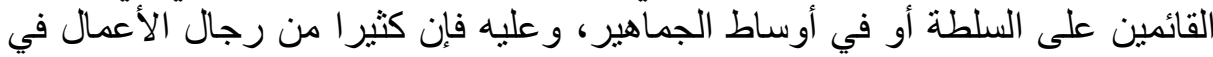

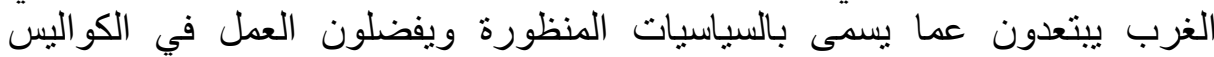

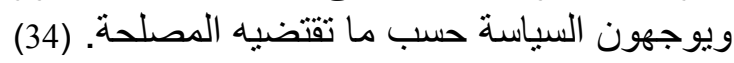

$$
\text { رابعا موقف الرأي العام : }
$$

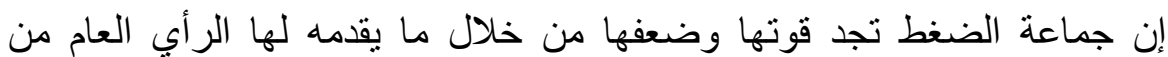

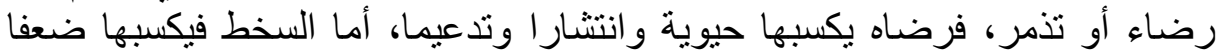

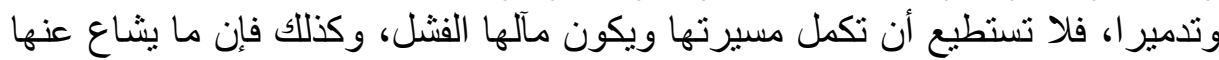

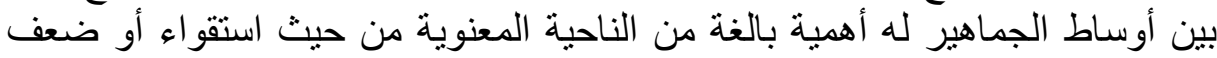

الجماعة. (35) - (35)

الخاتمــة

هذه بعض من الجوانب العامة المتصلة بالعمليات السياسية التي تقوم بها الجماعة التهاء

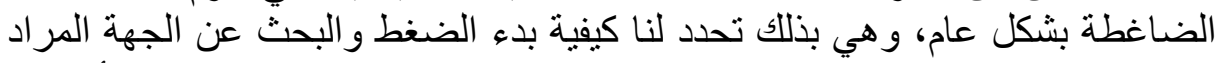

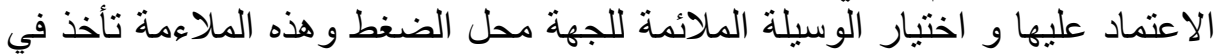
الاعتبار، والقوة التي معناها مدى توافر العناصر اللازمة لعملية الضغط الضادة ، من خبرة

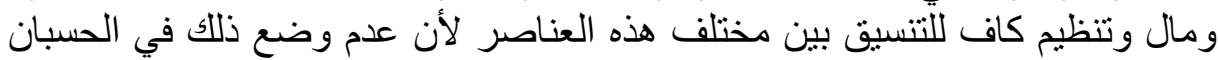

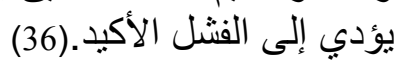

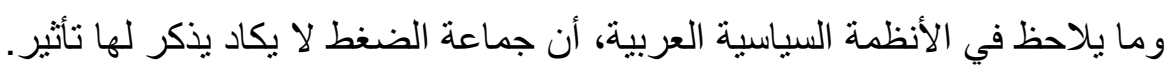

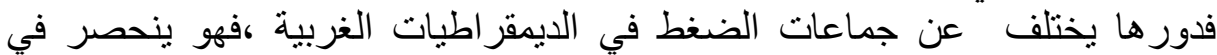

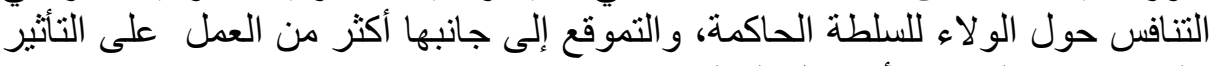
على قرارات الحكومة أو عمل البرلمان. 
1- أنور أحمد ارسلان - النظم السياسية،دار الفكر العربي القاهرة 1980 ص 217.

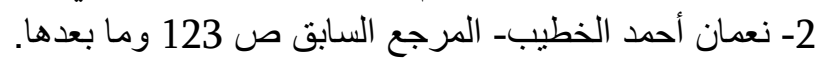

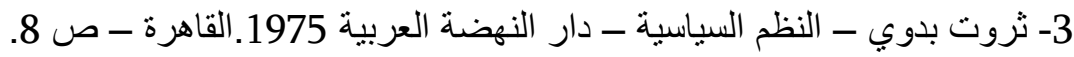

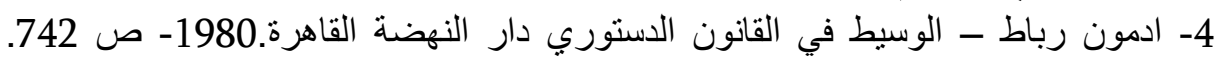

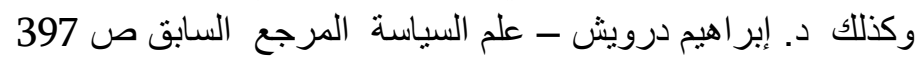

5- بر اهيم درويش - المرجع الساق صل 389. و و كنلك كلينتون روسيتر - المرجع السابق

6- عاصم احمد عجيلة، و محمد رفعت عبد الوهاب. النظم السياسية دار النهضة العربية ط

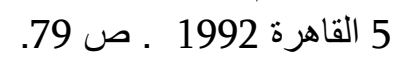

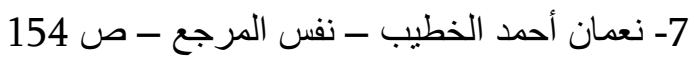

Antony Downs. Economic 8 ادمون رباط المرجع السابق ص 751.

.Theory of Democracy op. cit p 225

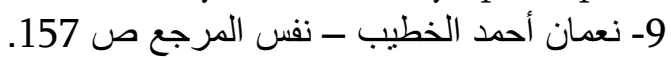

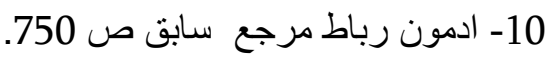

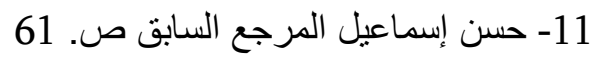

12- حسن سيد إسماعيل. النظام السياسي للولايات .م.أ و انجلترا دار النهضة العربية ط2

القاهرة 1977 1977 ص 58.

13- الثافعي أبو راس المرجع السابق ص 8. هـ و كذلك دكتور بطرس غالي. و محمود خيري

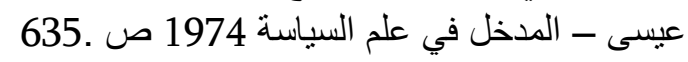

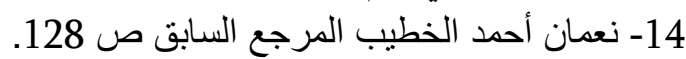

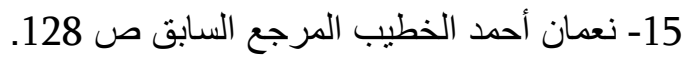

16- توجد تقسيمات كثيرة ومتتو عة لجماعات الضغط منها على سبيل المثال:

جماعات الضغط السياسية.

جماعات الضغط شبه النياسية.

جماعات الضغط الإنسانية.

جماعات الضغط ذات المبادئ و البرامج.

جماعات الضغط ذات المصلحة الخاصة.

جماعات منظمة و جماعات غير الفير منظمة.

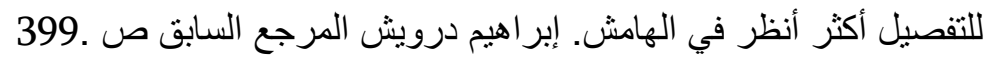

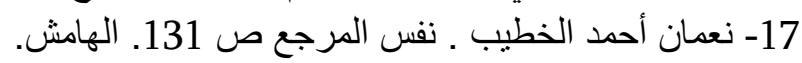

18- Maurice Duverger. Les partis politiques ouv. cit p . 132.

19- سعيد بوشعير. القانون الدستوري و النظم السياسية الدقارنة ج 1 النظرية العامة للاولة

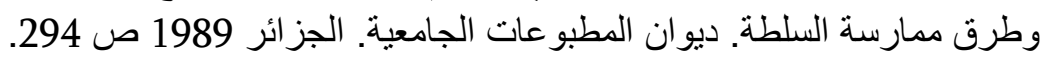

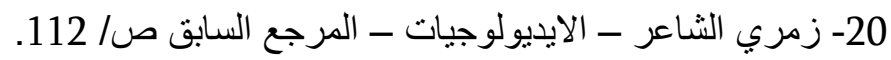




$$
\begin{aligned}
& \text { 21- هنري مخائيل ـ المرجع السابق ص 4. }
\end{aligned}
$$

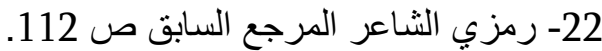

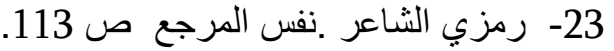

$$
\begin{aligned}
& \text { 24- هنري ميخائيل المبحث السابق ص } 134 .
\end{aligned}
$$

25- Lester W. Milbrath, The Washington Lobbyists .Chicago: Rand McNally, 1963.

$$
\begin{aligned}
& \text { 26- نعمان أحمد الخطيب نفس المرجع، ص ص 138. }
\end{aligned}
$$

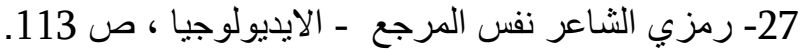

$$
\begin{aligned}
& \text { 28- نعمان أحمد الخطيب مرجع سابق، ص لفر } 140 .
\end{aligned}
$$

29- Gocuel .F et Grosser ， La politique en France ouv.cit p 131.

30- يقدر عدد المنخرطين في نقابة الاتحاد العام للعمال الجزائريين بثاثلة ملايين وزيادة،

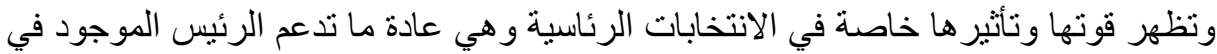
السلطة لقبول عهدة جديدة.

32-Leon .p. Baradat . op.cit, p 141.

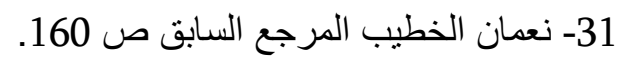

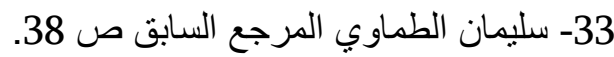

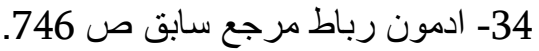

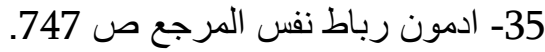

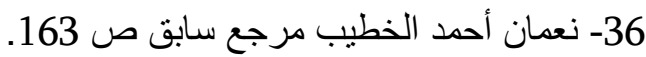

